\title{
Learning on the Job: The 1998 Squamish McDonald's Campaign and New Possibilities for Fast Food Workers
}

\author{
Jeremy Milloy
}

McDonald's has become synonymous with low-wage, low-status, highstress employment: the "McJob." But that did not deter Tessa Lowinger and Jennifer Wiebe from trying to make McJobs something better. Their 1998 battle to unionize McDonald's in Squamish, BC, was an important confrontation between Canadian workers and multinationals during the 1990s that attracted international media attention. The two young women, backed by a union experienced in representing service workers, successfully organized their McDonald's. Their campaign raised hopes of a long-sought union breakthrough in the service sector. However, just over a year later, McDonald's had triumphed and the union had decertified. Ultimately, the Squamish experience teaches us about the limits of traditional unionism for fast food workers in the current legislative framework and economic climate, and the need for workers, labour activists, and scholars of labour to continue to explore new options.

This paper combines previously unstudied internal union documents and interviews with union leaders with a consideration of how the Squamish campaign compares with other campaigns for worker representation at McDonald's globally. While I draw on the excellent literature about workers' struggles at McDonald's, my analysis of Squamish as a test case in global context leads me to depart significantly from the existing literature in one important respect. Where most scholars focus on the chances for traditional unionization to succeed in the fast food industry, this paper argues that the defeat at Squamish and McDonald's success thwarting workplace representation in a variety of national contexts demonstrates that traditional models of organization and collective bargaining are simply not feasible in this industry under current conditions. It then engages with the developing literature on both social movement unionism and new models and forms of employee representation, using the Squamish experience as a case study to evaluate current debates and probe what approaches may best aid fast food workers in increasing their power at the point of production. ${ }^{1}$

Organizing fast food workers has long been a concern of North American unions. In Canada, the government brokered a mid-century labourcapital-state détente, starting in 1944 with PC 1003. In the postwar era, the largest unions abandoned all pretenses to job control and expelled radical members and unions from the mainstream of the labour movement. In return, capital agreed to recognize the legitimacy of unionized labour to negotiate wages and benefits; and governments passed legislation that provided for some measure of union stability. The unionized employment landscape of the largely prosperous 
twenty-five years to 1970 was marked by rising wages, benefits, and job security, primarily for a white male worker in the manufacturing, resource extraction, and transportation sectors. However, this postwar accord was only temporary. When the rate of profit began falling globally in the late 1960s, coupled with rising commodity prices in the early 1970s, capital and the state began to systematically dismantle the welfare state, attack unions, and ferociously resist new organization. As capital moved most of its manufacturing facilities to non-union regions of the world, more employment shifted to the service and retail sector, workers who had largely remained outside of the efforts of trade unions until the 1970 s. $^{2}$ Labour unions that had neglected organizing new workers and become increasingly bureaucratic found themselves on the defensive. Assessing the BC situation, Ben Isitt concludes that BC workers had less capacity, at least through mainstream unions, to challenge the prerogatives of an increasingly global capitalist class, just when that capacity was needed to resist the rising tide of neoliberalism. ${ }^{3}$

In the 1990s, the major unions began to take notice of an aging membership and the growth of this primarily non-union work as a major employment sector. Some of them prioritized fast food organizing. There was much work to be done. In 1998, the year of the Squamish campaign, only eight per cent of workers in accommodation and food services belonged to a union. ${ }^{4}$ The Teamsters and the Hotel and Restaurant Employees Union (HERE) launched certification drives at McDonald's franchises in St. Hubert and Orangeville respectively. In the Teamsters campaign, ownership resorted to shutting down the restaurant rather than recognizing the union, an indication of how committed McDonald's was to staying union-free in North America. Unlike these unions, Canadian Auto Workers (CAW) Local 3000 had experience and success organizing the fast food sector. However, the fight at the Squamish McDonald's proved to be its highest profile and most challenging restaurant campaign yet. ${ }^{5}$ It is of particular interest as an example of the franchise system acting as a powerful barrier to unionization and a demonstration of the inequities of labour law in British Columbia. It prompts us to consider why the aggressive tactics of an experienced service work union still failed to keep the workplace certified. Considered in the global context, it is an instructive illustration of McDonald's ability to evade meaningful workplace representation, no matter what the regulatory context. Finally, it is a case study that can help us evaluate the possibilities and drawbacks of new and emerging forms of workplace organization.

The campaign at Squamish differed significantly from others undertaken in the same period, and these differences make it the key campaign to study. Unlike the other unions who attempted to organize fast food workers in the 1990s, including HERE, the Teamsters, and the SEIU, CAW 3000 had a deep 
background and expertise in fast food unionism. After its uneven early years, the union had become a responsive, democratic local with a keen understanding of the needs of fast food workers backed by the deep pockets of the CAW. It could boast a record of fighting, and winning, battles with corporate management. In his 2001 study of Local 3000 and young workers, sociologist Stuart Tannock noted the reputation the local had won across Canada as one of the most dedicated and effective unions representing youth and service workers. ${ }^{6}$ The drive benefitted from the leadership of workers who, while young, were union-wise because of their upbringing in Squamish, a town with many union members. Squamish's union density also meant the union and workers had solid community support, a significant benefit when attempting to organize a business dependent on public patronage. ${ }^{7}$ The Squamish campaign presented a nearly ideal opportunity to organize a McDonald's. If an experienced, democratic local with the resources to win could not beat the only McDonald's in a union town, what hope was there for success elsewhere?

Opened in 1987 by Paul Savage, the Squamish McDonald's sits beside the Sea-to-Sky highway, a busy road connecting the populous Lower Mainland of British Columbia to the leisure mecca of the Whistler-Blackcomb region. Many Squamish residents were unionized workers in the railroad and pulp and paper industries. ${ }^{8}$ The restaurant was often busy, and Grade 12 students Tessa Lowinger and Jennifer Wiebe soon tired of being screamed at by managers for trivial mistakes, often in front of dozens of customers. "I was taken out into the lobby and yelled at in front of customers and made to cry," recalled Lowinger. ${ }^{\text {? }}$ Eighteen year-old Billie Harrison also reported being dressed down in front of customers and sent crying to tell the customers the mistake she had made.

Reflecting on her treatment, she recalled, "They made me feel really small."10

This treatment of workers ran counter to standard McDonald's management strategy. To avoid unionization and to motivate employees without raising wages, the fast food chain has stressed positive reinforcement for workers and instilling a team concept to keep workers motivated and quiescent. In Fast Food Nation, Eric Schlosser describes a fast food industry conference where industry leaders discussed motivating employees without spending money, through employee awards, "teamwork, empowering workers, and making it "fun." Sociologist Robin Leidner, who did participant research at a McDonald's for her book Fast Food, Fast Talk, reflected that "the apparently respectful, evenhanded psychological management style that McDonald's encourages helped make the repetitive, fast-paced, low autonomy, low-paid jobs tolerable to workers." 11 Conversely, workers were angered when managers treated workers with disrespect.

Ester Reiter conducted participant research at Burger King for her 
landmark study Making Fast Food. She echoes Leidner's observations, indicating that the strategy is widespread across the industry. In the discourse of Burger King's management manuals, "Worker satisfaction is an individual phenomenon defined not through decent pay scales and working conditions, but in the less tangible area of psychological concepts." 12 Nor did this strategy originate with the fast food industry; Reiter points out that restaurant owners were using the theories of Elton Mayo as far back as the 1950s, in order to reduce turnover without raising wages. ${ }^{13}$

There were also safety concerns at the Squamish McDonald's. Sick employees were routinely pressured to stay on the job. If workers were absent because of illness, they were told to find a replacement before their absence would be condoned. Both Wiebe and Lowinger reported being forced to stay on site in the employees' bathroom for two hours after arriving at work sick with cramps and nausea, waiting for a replacement to arrive. Lowinger described unsafe work conditions. "One light switch had no panel," Lowinger said. "You'd actually get a shock when you touched it."14

How bad was working at the Squamish McDonald's? The question of what motivates workers to organize in the fast food industry is important for both scholars and labour activists. While most observers would view the McDonald's labour process as inherently difficult and alienating, it often appears to be specific, on-the-ground conflicts with individual managers and owners that prompt unionization drives, as is the case in many other workplaces. Indeed, Schlosser asserts, "the personality of a fast food restaurant's manager largely determined whether working there would be an enjoyable experience or an unpleasant one."15 Reiter, Leidner and Schlosser have observed that paternalistic management is the standard in the industry; however, the hectic pace of work and stress of serving the public often exposes cracks in the façade of work as fun. These stresses caused the campaign in Squamish and were also significant factors in Orangeville, where Sarah Inglis complained about management being rude, sexist, and "making people feel disgusting about themselves." 16 At the McDonald's in St. Hubert, it was reported that pro-union workers were tired of "the stresses of the job, of being yelled at until they cried."17

Beyond abusive management, wages, working conditions, and the labour process were also a major concern at both locations. In Orangeville, workers objected to the casualization of labour, especially when a new manager reduced the scheduled hours of several long-term employees. At St. Hubert, being timed with a stopwatch and not receiving raises after six years were key grievances. In the final analysis, it is difficult to separate the degrading treatment experienced by workers from McDonald's fundamental labour process, management strategies notwithstanding. In an industry that views its employees as costs 
to be relentlessly squeezed for maximum productivity at minimal wages, benefits, and security, the inherent exploitation of the job is always going to be visible to many workers. Reiter's conclusion, that "it is not traditional union sentiments that have spurred the moves to unionize, but unacceptable and arbitrary management practices," is an unhelpful simplification. First, grievances with arbitrary and unfair management have long been a prime motivator for union struggles in a variety of industries; the ability to defend oneself from capricious treatment and favouritism certainly seems a traditional union sentiment. Second, complaints over wages and working conditions were certainly motivating factors in the three Canadian campaigns to organize McDonald's restaurants.

Again, it is difficult and probably fruitless to try to separate dehumanizing and arbitrary treatment from the fast food model, no matter what the manuals state. Jennifer Talwar makes a poignant point when she observes that:

The fast food industry stresses temporary status, the contingency of industry need, and an income that gains societal contempt rather than respect. No wonder workers behind the counter suffer harassment from customers, feel they are not respected, and rarely wear their uniforms in public. The premium placed on customer service, the shaping of personality, and the dichotomizing of feelings between work and home further widens the gap between private life and work life and poses a contradiction for the fast food organization. The more the gap widens, the more managers are required to gain control over the private lives and emotions of their workers. ${ }^{18}$

Fast food work poses the same contradictions for labour unions and activists as it does for managers. The examples show there is clearly a demand for pride, dignity, and respect as well as better wages and conditions. The question is: what sort of organizing can harness those demands and effectively increase the power of these workers in such low-status, dehumanizing, and precarious jobs?

Unlike Lowinger and Wiebe, most of the sector's workers respond to unhappiness by voting with their feet. The commonality of turnover is one clue to how widespread dissatisfaction among workers is, and how little workers expect from these employers. Most often, poor treatment at work or dissatisfaction with pay, benefits, or processes is dealt with by exchanging a poor job at McDonald's with a new one at Home Depot, Tim Horton's, or the Gap. Lowinger and Wiebe could have quit. Instead, they decided to organize. In July 1998, the two women voiced their concerns to Lowinger's father, Hans, a BC Rail worker and CAW member. Hans called his steward, who contacted Roger Crowther, an organizer at CAW 3000. At this time card check, a system that automatically certified a union when enough workers signed union cards, was a legal means of organizing in BC. Wiebe and Lowinger canvassed their coworkers 
at their homes, and quickly enlisted more than 55 per cent of 78 workers, exceeding the minimum necessary for automatic union certification. Franchise owner Paul Savage challenged the vote at the Labour Relations Board, claiming that not all workers were given a chance to cast ballots. In fact, the 28 workers he claimed had been disenfranchised were new employees hired specifically to dilute union support and halt the drive. In one early pay period during the dispute, the number of employees skyrocketed from 74 to 104, part of Savage's plan to dilute the mass of pro-union workers. ${ }^{19}$

It should be noted that the certification would likely never have happened without the BC labour law provision for certification by card check. Under card check certification, once a mandated percentage of workers have signed a union card, certification procedures can begin. By contrast, the United States and some other Canadian jurisdictions first require card signing and then an election for certification. This is a lengthy process that allows employers time to intimidate workers and hire new ones to dilute union support. In his book Differences That Matter: Social Policy and The Working Poor in The United States and Canada, sociologist Dan Zuberi identifies card check as the major reason for the higher union density among British Columbia workers compared to workers in the US. Abolishing card check was one of the first acts of the right-wing BC Liberal government after their election in 2001.20

Another challenge to the certification vote came from within. In August, Vancouver labour lawyer Randy Kaardal, representing a group of "a dozen or so" anti-union employees, submitted a brief to the Labour Relations Board contending that Squamish employees could not accept a contract for union representation because they were below the age of majority. The Board disagreed, recognizing that these workers were old enough to accept employment, and thus were old enough to join a union. It also pointed out that Kaardal's argument contradicted labour law precedent. The nature of Kaardal's involvement raised several questions. How could a group of teenagers making between seven and nine dollars an hour afford the services of a lawyer who customarily billed $\$ 250$ for an hour of his labour? If they were old enough to retain a lawyer, how were they then too young to sign contracts? Kardaal denied that he actually represented McDonald's or Savage, and maintained that he had slashed his fees for this case because of "principle reasons." 21

After the board's decision, Savage temporarily retreated, and agreed to recognize the certification. Unlike the Cappellis of Montreal, who closed down their St-Hubert McDonald's franchise in response to a union drive, Savage stated he would not close the Squamish location. With that, the Squamish McDonald's became the only unionized Golden Arches in North America. ${ }^{22}$ While they certainly had much work to do before a first contract, this victory alone was a sig- 
nificant step beyond what workers had achieved in other countries. The workers who had some form of representation at McDonald's did so in countries where some form of sectoral bargaining or access to works councils had been legislated upon McDonald's, usually with little actual impact on wages, benefits, and work conditions. ${ }^{23}$ Like other traditional campaigns in the United States, McDonald's had defeated the earlier Canadian campaigns in St. Hubert and Orangeville. In St. Hubert, the company and franchisees resorted to closing the outlet; in Orangeville McDonald's challenged the certification, improved working conditions, doled out fringe benefits like free food, and reportedly intimidated workers. ${ }^{24}$ Savage and the company would employ similar strategies to combat Wiebe, Lowinger, and CAW 3000 in Squamish.

The media soon flocked to tell the story of the unlikely victory. Most accounts focused on the youth of Wiebe and Lowinger and the David versus Goliath dynamic of their struggle. In a telling revelation of how antagonistic restaurants had become towards organized workers, the chief of the BC Restaurant and Foodservice Organization, the provincial employers' group, was quoted as calling the certification "obviously disappointing." Relations had changed from the more cooperative attitude between restaurateurs and unions that existed in the 1950s and 60s, when unionism in BC restaurants was not uncommon. ${ }^{25} \mathrm{He}$ was quick to reassure other bosses that Squamish was "not a trend. It's optimistic for them to think that it is." 26

The Vancouver Province's editorial board also raised the usual spectres in response to the CAW victory. According to the Province, this action by a few workers at one of hundreds of BC McDonalds' threatened the economic future of the entire province. Saying that the victory would be an inspiration to organizers and workers across $\mathrm{BC}$, the newspaper paused to worry about the people "who want to invest their money somewhere... Will they look at BC, freeze at the thought of this precedent and then take their business elsewhere?" While the Province congratulated the Squamish workers on their victory, its conclusion both demeaned their work and age, portraying them as something less than actual workers worthy of having their concerns addressed seriously. The statement that "these kids are flipping burgers, and many aren't in it for the long haul. Isn't the job itself enough?" raises some obvious questions. If these "kids" were only "flipping burgers," how could their unionization be "D-Day for the health of British Columbia," an action so radical and far-reaching that it would drive away outside investment and plunge the province into recession? While the Province would not engage with fast food work seriously, it did seem seriously concerned that workers and unions might. ${ }^{27}$

The frenzied media speculation was premature. Before Wiebe, Lowinger, and CAW 3000 could torpedo the BC economy, they would have to 
move beyond certification and become the only union in North America to sign a collective agreement with McDonald's. Negotiations began in September, and immediately bogged down in the face of employer intransigence. On the face of it, the workers' demands were modest: a small wage increase, some employee benefits, seniority considered in scheduling, and an anti-harassment policy. The real goal was to solidify the union as a viable bargaining unit. But to McDonald's, the demand for a collective agreement was outrageous in itself. Savage and The corporation endeavored to slow the process to a halt. This would be the cornerstone of their method to remain union-free. ${ }^{28}$

Why was McDonald's so determined to keep the union out? As many scholars have pointed out, unionization is a direct challenge to the McDonald's model on several levels. While scholars are right to criticize George Ritzer's theory of McDonaldization, (that McDonald's process of rationalization is creating an increasingly homogenous yet unstable world), as insufficiently attentive to local differences, none disagree with his observation that McDonald's attempts to operate along standard lines globally as much as possible. ${ }^{29}$ Royle and Tarwar have both observed that McDonald's desires a high level of worker identification, a reason why paternalistic managerial relations are encouraged to wed workers to McDonald's processes. This is necessary to win the consent of workers of whom sociologists Julia R. Woodhall and Alicia Muzsynski conclude: "experience the worst of both the Fordist and post-Fordist models. They participate in a precarious, flexible job market, which is said to alleviate some of the problems of Fordism. However, the actual labour and daily operations performed by these workers is organized along Fordist lines, forcing participation in alienating work." 30

A trade union in the workplace would challenge this mode of work organization. It would contest the power of McDonald's to manage production and service by fiat, especially in the realm of scheduling how many hours to give employees and how many employees to use per shift, so key to managing labour costs. It would also push for higher wages. Finally, the union itself would present an alternate focus for employee affinity, which runs counter to management strategy. The desire among McDonald's executives to remain anti-union extends beyond their efforts to remain union-free in Canada, the United States, and the UK. In countries like Germany, Spain, the Netherlands, and elsewhere, where McDonald's has been forced to recognize various forms of employee representation, the company has assiduously worked to marginalize these institutions and keep as free a hand in employee relations and store operations as possible. ${ }^{31}$ Seeing unions as not only a threat to profits and managerial prerogatives, but to the very operations model that has underpinned the chain's success, McDonald's was always going to be a determined adversary of unionization in Squamish. 
After weeks of desultory negotiations, Crowther held a successful strike vote to try to jump-start the proceedings, maintain union solidarity, and give the bargaining committee a strong mandate. By March, after eight months of negotiations with mediator Jim Breckenridge, a settlement package was on the table. Crowther was disappointed by the workers' emphasis on fair treatment, as opposed to a more equitable pay package, but noted the workers had already won their anti-harassment and seniority provisions, "legal rights in the workplace that no other employees at McDonald's [have]." 32 The Squamish workers voted 100 per cent in favour of the contract, but McDonald's had other ideas. Instead of accepting the mediated agreement, they petitioned the Labour Board to allow the parties to proceed to a strike or lockout, in hopes of a decertification battle. Their refusal to accept a mediated settlement indicates that their initial strategy, to play for time until they could destroy the union, had not changed since the first certification vote.

Crowther and the local CAW leadership attempted to keep workers onside throughout what became a negotiating marathon by stressing the gains the union had made for workers at organized fast-food outlets elsewhere. In a notice posted to employees explaining the purpose of the strike vote, Crowther claimed that, "it is agreed by most observers that the CAW/KFC contract covering $47 \mathrm{KFC}$ restaurants is the leading fast food contract is [sic] North America. The start rate is $\$ 8.07$ per hour.” In comparison, BC’s minimum wage was $\$ 7.15$ in 1998. However, Crowther well knew that these restaurants were organized at a much earlier time, and the union then had possessed two advantages, the corporate ownership of those KFCs and the union density provided by the 1973 blanket certification and later master agreement, that were not in place in organizing the Squamish McDonald's. ${ }^{33}$ Meanwhile, McDonald's argued before the Labour Relations Board (LRB) that the strike vote was invalid. Because workers were told that there would necessarily be another vote before strike action, they held that this vote was administrative in nature, and therefore meaningless. While the appeal was yet another stalling tactic dismissed by the LRB due to lack of merit, the testimony provided contains valuable information about the campaign. ${ }^{34}$

A review of the Board's decision demonstrates that Local 3000 leaders did a good job of providing information to its members, largely teenagers with little trade union experience. One worker, Joe Mahlberg "agreed that the Union provided several reasons why employees should vote "yes". These reasons included sending a message to the Employer that the employees were serious; moving along negotiations; and accessing the Section 55 mediation process." 35 Organizers also tried to soothe employees who had learned of McDonald's reaction to successful unionization, as the threat of a shutdown was a common scare tactic during a union drive. Crowther reassured them in a handout that 
"the company stated once again in front of the mediator - they will not close the restaurant. Don't listen to rumours or those who are not at the bargaining table."36

LRB testimony indicates that many workers were not persuaded by the threats of closure. Discussing the strike vote meeting, worker Kirsten Albrighton testified, "The employees smiled when Lowinger asked if they believed that the restaurant would close and laughed when she asked if anyone believed that "bad things" would happen."37 However, these reassurances show the union understood that keeping workers together would be even more difficult than the initial organization. This was especially true for workers with little security to begin with. Simple fatigue with a drawn-out, complicated process was another hurdle for workers and organizers. Albrighton's testimony touches on both of these themes: "she felt that the employees were scared and that Lowinger reassured them that they would not likely go on strike. She felt that a "yes" vote would "speed things up" and "get it over with" as the "kids were bored with it."38

Crowther and CAW organizer Denise Kellahan also attempted to drive home who bore responsibility for the numerous challenges and delays, reminding workers that the dispute was with Savage, but also with the powerful corporation behind him. In one update, the CAW noted that of the union's demands, Savage's lawyer only objected to a laundry allowance and a higher start rate. Crowther and Kellahan asked 'If we are only dealing with the franchise owner, why the worry...? They have spent thousands of dollars in legal fees just to prevent a higher start rate? Who is really calling the shots here?"39 The union repeatedly demanded to know who was paying Savage's legal fees, estimated at half a million dollars by the end of the dispute. Savage claimed loans and pro bono work were carrying the load.

In his own series of notices to employees, Savage attempted to sow fear and dissent. He pointed out that the mediator could pursue several options, including granting parties their right to a strike or lockout, raising fears that a contract was really no closer. In his handouts to employees, Savage also warned of union red tape, saying the union's proposals would result in "less [sic] employees and far less flexibility than we currently have." $40 \mathrm{He}$ reiterated that the restaurant was in poor financial shape, a claim he said the union had agreed with. Implicit in statements such as "it may be hard to believe the restaurant is performing so poorly" or "this business has to turn around and become profitable" is the threat of closure in an "intensely competitive" market like Squamish. ${ }^{41}$ Even the pro-business Globe and Mail was skeptical of Savage's tales of financial distress, writing that, because of its location on a major highway and near a high school, the Squamish outlet was "reputed to be the third most prosperous in British Columbia." 42

Furthermore, some of Savage's losses and his lower per shift profit averages were not based on normal operations, but on his attempts to buy his way out of his union problem, according to both Kellahan and a Globe and Mail article on the dispute. Kellahan claimed that during the drive, Savage followed a policy of placating young employees by 
vastly over-scheduling workers per shift, allowing them a chance to earn more money in a very social atmosphere, with much less work to do. This was an attempt to chip away at pro-union sentiment by making him over into a friendly boss who made McDonald's a fun workplace. ${ }^{43}$ Savage and his team of new managers and advisers also responded to unionization by fixing the electrical outlets, holding meetings to hear grievances, and buying a new staff room stereo. They showered staff with free pins, meals, and banana splits. Worker Dan Duggan noted, "if it was always like that, I wouldn't be for the union." 44

Indeed, throughout the dispute Savage countered the union's rhetoric of brotherhood and sisterhood with his paternalism. In addition to parties and social shifts jammed with employees, he tried to inculcate a family feeling in his notices. One relates his pride in his workers graduating from high school, concluding that "Watching our students succeed at school and at work is one of the big reasons I enjoy operating this restaurant." 45 Another notice began brightly, talking about the "great time" Savage had at the Christmas party where "everyone was enjoying themselves." "Unfortunately," the letter continues, "T have to respond once again to the recent question and answer from Denise Kellahan." 46 Here Savage shrewdly constructed himself as a friendly boss who could provide fun for everyone, if the union would just stop interfering.

This paternal discourse was combined with continued obstruction. When his appeal of the strike vote was rejected by the LRB, Savage next claimed that employees did not have "adequate time" to decide. One union employee, Ben Thompson, claimed that only 15 of 85 employees had participated in the strike vote. In fact, since certification, Savage's McDonald's had undertaken a churn of its employees. Pro-union workers had their hours cut as an incentive to leave. New anti-union workers were hired, with opposition to CAW 3000 purportedly a condition for employment. Reiter claims that 28 new employees were hired immediately after the certification application; while the exact timing and scale of the new hiring is elusive, it seems almost certain that diluting the pool of disgruntled, pro-union employees was a key part of Savage's strategy. ${ }^{47}$ Though it is uncertain how many employees participated, it was reported that at least 18 boycotted the vote, meaning many more anti-union employees were at the store. ${ }^{48}$ Despite this, even employees testifying in favour of Savage agreed that the strike vote meeting was clear, informative, and free of harassment or coercion. Again, the practices of the union were proven to be legal and transparent, despite the rhetoric of Savage and McDonald's.

The dispute dragged on. High turnover at the restaurant and the deep pockets and rabid anti-unionism of McDonald's shifted the advantage to the employer. While the Labour Relations Board upheld the original strike vote and upheld it again on appeal, one piece of $\mathrm{BC}$ labour law dealt a critical blow to the fight to obtain a collective agreement. $\mathrm{BC}$ law allowed decertification, a vote to disband the union, to proceed just 10 months after the union had been certified. Unlike Ontario law, which mandated that at least one collective agreement being signed before a decertification, workers in BC could decertify 
without even having the chance to see the pros and cons ofworking with a union contract. ${ }^{49}$ This provision made it possible for Savage and McDonald's to stall and flood the workplace with pro-management workers to wait the union out and prepare for a decertification vote without bargaining seriously. Crowther and Kellahan alleged that was what had happened. On 3 July 1999, a vote took place, with 45 workers voting for and 25 against decertification. Over $50 \%$ of the voters had not been working there just 10 months earlier, when the union drive took place.

The varied reactions of workers were an apt reflection of their nowbitterly divided workplace. Some, like Jenn Thiele, clearly believed the SavageMcDonald's line, saying "if we get the union then McDonald's will buy out [owner] Paul Savage and [the workers] will lose their jobs." Kris Pienatkowski seemed to believe that the union was unnecessary to ensure lasting changes at his workplace. He predicted hopefully, "I think that having this thing, it scared them. Now they are going to treat us good, because we have power to do stuff." 50 Joe Mahlberg, the 19-year-old employee who was the face of the antiunion campaign, exulted in the result, saying, "We finally got our say. We've been heard. We'd like to see the union pack up and march away."51

Mahlberg's comments indicate another key weakness in the traditional collective bargaining model as it applies to the fast food industry. It is immensely difficult for workplace leaders and outside organizers to keep all workers onside during a long and difficult fight against an employer, particularly one that is willing to make positive changes to the workplace in order to stay union-free. The ability of the employer to play divide and conquer among young workers in a high turnover industry has been a consistent obstacle for attempts to unionize in this sector. Organizations that have the capacity to help those workers who wish to change their working conditions while not requiring the consent of most members to support that activism may offer a way past this common impasse.

Wiebe and Lowinger were crushed, but still claimed a partial victory, and expressed optimism that their struggle would be taken up by other workers. "Of course I'm disappointed," Lowinger commented. "I don't understand what people wanted, why they thought they had no right to health and safety and to be treated fairly." Despite her obvious frustration, Lowinger concluded with a message of hope: "Don't let this discourage you," Lowinger said. "If more people try, then one day McDonald's is going to be union."52

At this writing, the Squamish outlet remains operating and non-unionized, like every other McDonald's location in North America. Reflecting on the dispute, which he was involved with from an early stage, CAW youth organizer and former White Spot worker Ryan Krell opined that, "one of two things hap- 
pens when an employer finds out about an organizing campaign. They call lawyers or they go ballistic, immediately harassing and disciplining employees unjustly. Of the two methods, lawyers and union-busting consultants are far more effective because they can turn the workers against one another." 53 These were the tactics used by McDonald's in all three Canadian union campaigns they thwarted in the 1990s.

Why was the union drive in Squamish defeated? Should Local 3000 have done better? If the union can be faulted, perhaps its tactics were too traditional. The Squamish campaign was a classic example of a "hot-shop" campaign, where organizers respond to grievances at a workplace and attempt to help translate those dynamics into a union certification and negotiated contract. The unions who have grown fastest in the past three decades, such as the Service Employees International Union (SEIU) or HERE, have increasingly abandoned this approach in favour of comprehensive campaigns. ${ }^{54}$ While no two comprehensive campaigns are identical, common tactics include bringing the issue to political leaders, attacking the corporation on matters apart from the affected workplace, and mobilizing rank-and-file workers and the wider community to force capital to the table. Despite the strong union tradition in Squamish, Local 3000 did not seriously attempt to mobilize the community, nor did it prevail upon the local government or the provincial NDP to try to break McDonald's stalling tactics. While it is unclear how effective this approach would have been a local boycott may not have had much impact at a restaurant beside a major highway reliant on transient business, and the NDP may have been unwilling to intervene - it certainly may have kept momentum going and increased the pressure on McDonald's.

However, any errors made by the union were not decisive factors in the failure to win a first contract. In any campaign featuring such a disparity in resources between workers and management, particularly in a high turnover industry, speed is critical for success. The fact that BC labour laws allowed management to stall and make a farce of negotiations, all the while replacing workers with anti-union hires, represented a failure of provincial law in the face of an embattled labour movement, and a prevailing pro-business hegemony, not of Local 3000. However, the defeat has put a chill on the local's restaurant organizing efforts, though it continues to represent many restaurant workers in BC.

The effort to organize the Squamish McDonald's did not live and die in silence. Like the other attempts to organize McDonald's franchises it attracted ample publicity for the union movement and for the grievances of fast food workers. The amount of investment in branding undertaken by multinationals allows for a certain amount of asymmetrical warfare by smaller adversaries. ${ }^{55}$ Their branding is so conspicuous and so key to their endeavors and financial 
health that these types of campaigns are highly visible. At the level of economics, however, the resources of multinationals and the unsympathetic climate of $\mathrm{BC}$ labour law, the result of business lobbying and anti-labour governments, have stymied unionization efforts.

Another reason why the organizing drive at Squamish failed was the franchise model under which the outlet operated. Analysts of McDonald's have concluded that the franchise model at McDonald's produces not a "loose federation" of independent franchisees but direct control by the corporation. Under its agreements with its franchisees, McDonald's retains the power to revoke franchises for any violation of its operating code. This includes labour relations, the standards of which are set by senior managers at head office. Franchisees are thus highly motivated to satisfy corporate management, both to retain their business and to have the opportunity to run additional franchises in their region. They also experience high levels of training and surveillance by McDonald's. In the 1970s, franchisees created a McDonald's Operators Association to address many grievances they had with the corporation. While the organization quickly foundered after McDonald's addressed some of the complaints, the event is a telling illustration of the labour/management-style dynamic that has existed. Royle points out that former McDonald's owner Ray Kroc's innovation was to transform fast food franchising from a quick sale of recipes and trademarks (like Nat Bailey's purchase of the BC KFC rights from Colonel Sanders) to a longterm, micro-managed relationship in which single restaurant licenses were sold, not territorial rights. In doing so, Kroc created "a club" to hold over the heads of franchise operators. For a franchisee facing a union drive, like Savage, the prospect of that club descending was likely very real and very urgent. ${ }^{56}$

However, during the 1998 campaign few observers were able to parse the labour-management relationship at McDonald's, and thus the franchise system provided an effective rhetorical weapon for Savage. Some might scoff at Fraser Institute head Michael Walker's take on the dispute, that "Very often, unionization sounds the death knell for small businesses,"57 but such a characterization was not entirely baseless. Despite owning an outlet of the richest restaurant chain on the planet, Savage was able to portray himself as a small businessman taking on a big union, and thus deflect some of the stigma of an unscrupulous owner fighting to deny rights from his teenage workforce. Furthermore, his claims of financial losses, incurred as part of the anti-union strategy, were much more credible as an owner-operator, than as part of McDonald's, the world's largest restaurant conglomerate. The McDonald's corporation, of course, would have had neither advantage in fighting a drive at a company-owned store. Accounts of chain-wide losses would have been ludicrous, and the company could easily be portrayed as a faceless corporate giant crushing plucky local teenage workers. The remarks of Mahlberg and other employees after the drive's 
failure signal that Savage's rhetoric, coupled with his self-presentation as a friendly boss trying to work things out with his employees without outside interference, resonated with enough workers to win the decertification vote. However, his success in halting the drive was fundamentally a simple matter of stalling to gain the advantages conferred by economics and staff turnover. Therefore, the $\mathrm{BC}$ labour relations regime was not adequate to serve to the clear desire of workers to unionize their McDonald's and reach a collective agreement with their employer.

However, other labour law codes around the world, including many that seem more favourable to workers and unions, have done little to encourage meaningful workplace representation at McDonald's. Sectoral bargaining and some form of automatic workplace representation have been applied to McDonald's in many European countries, but the company has largely effectively stymied any real bargaining in its European outlets. This indicates that real worker rights at McDonald's are not something that can simply be legislated from above. Surveying the global situation, Royle and Towers conclude that "whatever the systems of employee representation in countries.... large [Multinational Corporations] have been able to tame, neutralize, or subvert these systems, particularly at the workplace level." 58 The correct combination of legal framework and union strategy remains elusive in the fast food workplace. 59

The contrasting success of Local 3000 in organizing Vancouver Starbucks locations the previous year throws the differences in organizing a corporate chain, as opposed to a franchise, into sharp relief. At Starbucks, all outlets were owned directly by the corporation. The CAW had an easier time pressuring the chain, applying resources at several locations and eventually organizing them into a master agreement, similar to the one operating at White Spot and KFC. These provide a huge boost to unionization because instead of having to fight to establish a new local for each outlet, locations can be quickly added to a broad certification. ${ }^{60}$ However, the ultimate decertification of these unions further underlines the difficulty of using conventional bargaining to make lasting changes in the industry workplace, whether facing a corporate head office or an individual franchisee across the table.

Starbucks was also an easier target because of its brand positioning. The company has self-consciously modeled an upscale, quasi-hip image since its inception. Part of that image included marketing itself as an ethical employer. As Laurie Bonang, one of the Vancouver union organizers recalled, "I applied at Starbucks. I could get benefits. It was a really neat, trendy company to work for. I could say, 'I work at Starbucks, aren't you jealous of me?' But over time I could see that it [benefits, etc.] was a bone they could throw to us to keep us happy. When they could do so much more." 61 Starbucks's benefits, so good for public 
relations, rebounded on the corporation. Emboldened workers, who possessed a small measure of job stability because of Starbucks's lower-turnover philosophy, pushed the company to live up to its promises. McDonald's and other fast food restaurants have chosen to make no such offers, subtly promoting the discourse in their advertising that their workers are "kids" who aren't really working real jobs. Ten years after Squamish, this strategy continues to work effectively for the burger behemoths.

Nevertheless, the labour movement needs to fight for and attract fast food workers if it wishes to reverse its declining fortunes. Because of their youth, their numbers, their exploitation, and the fact that many are in their first jobs, they are exactly where labour needs to be. However, it is undeniable that, despite some fleeting successes, the mainstream unions have been an ineffective vehicle for organizing and defending the rights of service workers. This is especially true at the fast food multinationals that have achieved a hegemonic position in the restaurant industry since their advent in the 1950s.

The issues faced by the CAW in Squamish are not confined to the fast food sector, but are common in struggles to organize precarious work at highprofile employers. Wal-Mart, now the world's largest company as measured by annual revenues and number of employees, is a major recent organizing target of the CLC and UFCW. Battles to organize Wal-Marts, especially in Jonquiere, Quebec, where the company closed down an outlet to thwart a successful union bid, have mirrored the union-busting techniques perfected by McDonald's and the other fast food giants. ${ }^{62}$ It is clear that the McDonald's model is becoming the reality for more workers, not fewer. It is equally clear that traditional organizing strategies are ineffective here. What does this mean for labour scholars. For labour itself?

Wal-Mart's rise to the top of the global corporate structure represents the final death knell of postwar Fordism, especially its paternalistic offer of stability for workers in exchange for political moderation and constantly rising production. It has been replaced by the installation of the labour principles - low wages, instability, surveillance, and intimidation - experienced by fast food workers since at least the 1970s. Workers in BC responded by building Local 3000, but they are a notable exception. These practices have become the bedrock of capital's approach to labour in the service industry and throughout the Canadian economy. As Leah Vosko states, "Precarious employment is a defining feature of the Canadian labour market, yet it is poorly understood and the consequences are far reaching. They include our inability to apprehend the nature of and scope of labour market insecurity, misdiagnoses of work-related sources of ill health, the growing misfit between labour law and policy and workers in need of protection, and legal and institutional obstacles inhibiting vulnerable members of soci- 
ety from expressing their voices collectively." 63 Fast food is an important type of labour that historians and other scholars must reckon with in order to understand the growing exploitation of workers in an economy built on precarious labour.

Where do fast food workers go from here? During the past two decades, labour scholars and union activists alike in both Canada the United States have vigorously debated how to reverse decades of declining unionization rates. In the first chapter of Kate Bronfenbrenner a visible and important relationship with's pathbreaking book Organizing to Win: New Research on Union Strategies, Bronfenbrenner and Tom Juravich called for organizing tactics that engaged rank-and-file workers as leaders, creatively and aggressively pressured employers on multiple fronts away from the workplace, and effectively engaged other community organizations - what is now commonly known as social unionism or social movement unionism. ${ }^{64}$ In his Restoring The Power of Unions, labour historian Julius Getman analyzes the history and strategy of HERE, probably the most effective social movement union. Getman concludes that the comprehensive campaigns pioneered by HERE are the only realistic option for organizing new workers: "the union learned... that organizing is a complex process and that at its heart is the mobilization of the membership and the application of relentless pressure to recalcitrant employers." 65 Undoubtedly, HERE has had some notable organizing successes using comprehensive campaigns, especially in the hotel sector.

However, social unionism is not without its detractors. Labour journalist Steve Early has tenaciously criticized SEIU, one of the unions represented in Bronfenbrenner's book and North America's fastest-growing union, for negotiating sweetheart contracts with employers, ignoring the real concerns of rank and file workers, and suppressing democracy and worker engagement with top-down control, often through the method of union trusteeships. Getman is also critical of SEIU for raiding HERE. ${ }^{66}$ While HERE appears to offer a powerful counter-example of a union that has balanced growth with adherence to democratic, worker-led principles, constant vigilance is required to ensure that the concerns of workers are not bypassed by unions seeking to expand by any means necessary.

Canadian social unionism has been accused of an overreliance on legal panaceas and a fundamental conservatism. In reviewing social unionism in the agricultural sector, Butovsky and Smith argue that "The social unionist official can "talk the talk" (and often with great passion and urgency) but fails to "walk the walk," relying on litigation and electoral activity in support of the New Democratic Party that promise, at best, a glacial pace of social change." 67 David Camfield cautions against solutions designed to pump new blood into tiring 
unions, insisting that motivation should derive not from "revitalizing the movement" but rather from "directly impacting day to day lives," starting with workers' concerns and "actually existing worker's resistance." 68

For those interested in increasing the power of fast food workers, such concerns of principle and philosophy, while important, are overshadowed by the prosaic reservation that social unionism and comprehensive campaigns may simply not be effective in fast food workplaces. Lowinger, Wiebe, and CAW 3000, were able to certify a union at the Squamish McDonald's without the techniques of social unionism. Where they were stymied was in negotiating a contract. Could a comprehensive campaign have secured an agreement, or would McDonald's have stood firm, using the shield of franchise ownership to deflect pressure while counting on turnover to destabilize the certification? Getman rightly notes many of the successes HERE have had in organizing hotels, casinos, and university cleaning staffs thought previously unorganizable.

However, those workplaces require far more employees, accounting for a great deal of local economic activity in their communities and thus having commensurately sized obligations and needs from local government. Would similar pressure or community interest exist at an independently owned McDonald's that employs 30 to 40 workers? During the Squamish campaign, Bryan Palmer noted that the dues money and political power gained by organizing fast food workers was limited. He also observed "You spend all your money organizing one branch, employers can close it down, and move employees around," said Palmer. "You can't do that with an auto plant."69

Furthermore, community support in a restaurant strike is no guarantee of success. In their discussions of the 1978-83 Muckamuck restaurant labour dispute, both Smith and Nicol detail the wealth of support the strikers received from organized labour, supportive locals, and aboriginal communities (most workers at the restaurant, which served aboriginal cuisine, were First Nations). Nevertheless, the strike failed in the face of employer intransigence, high turnover, and a labour relations board that consistently stalled on employer violations while quickly punishing the union for picketing infractions. Detroit's ACORN-backed United Labor Unions used similar strategies in an effort to organize fast food workers in the early-1980s. Despite widespread labour and community support and worker enthusiasm, the attempt was defeated by employer resistance and high employee turnover. ${ }^{70}$

In their introduction to Organizing to Win, Bronfenbrenner et al refer to a small body of case study literature analyzing how and why organizing campaigns succeed or fail. This study of the Squamish campaign can be added to that body, and it indicates that the methods of social unionism, while effective in 
some settings, may not work for fast food workers. Even if done with the best intentions, it is still unproven that the methods of organization and negotiation pioneered by HERE can deliver results for the precariously employed workers of the fast food sector. The strongest piece of evidence pointing to this conclusion is the stark fact that these methods have yet to be successfully used in obtaining a union contract at a single fast food restaurant in North America. Changing this would require a militant, massive campaign aimed at simultaneously organizing every outlet of a particular chain in a particular area, supported by a mass media campaign, mobilization of a variety of different unions, and boycotts.

Even then, success is far from guaranteed, and it is doubtful whether mainstream unions would harness the amount of resources this would require to organize workers at unstable jobs at a relative handful of small outlets. If organization were successful, securing first contracts would be an even larger battle, requiring a greater and longer-lasting mobilization. Getman quotes Jeff Fiedler, "the guru of the comprehensive campaign" dismissing the legal environment of organization by insisting that, "the Board is irrelevant to me. If the workers want to organize and you understand the company, you can win."71 Clearly, there have been many groups of fast food workers who have wanted to organize. Perhaps mainstream unions have failed to understand fast food companies, and the strategies needed to organize them.

Fortunately, both scholars and activists are exploring a variety of different worker organizations in an attempt to overcome the obstacles to organizing for fast food and other precarious service sector workers. Wade Rathke, in his study of organizing possibilities at Wal-Mart, calls for a minority unionism not tied to collective bargaining, but to building a critical mass of present and past workers. These organizations can give workers experience in building movements, direct democracy, combating capital, and developing leaders. Writes Rathke, "Building an organization has always been the prelude, not the consequence, of collective bargaining." 72

Minority unionism is a non-statutory form of organizing in which only those workers who wish to participate are union members. No certification is required for the union to act at the workplace; conversely, the members have none of the legal protections extended to a traditional union in the midst of an organizing campaign. These "Members only," voluntary, not mandatory, unions are still provided for in US law. Legal scholar Charles Morris is a prominent advocate of minority unionism in the United States. His book The Blue Eagle at Work: Reclaiming Democracy in the American Workplace, argues that the National Labor Relations Act (NRLA) requires employers to negotiate with groups of employees (not unions). To Morris, the minority unionism that the act provides for has the potential to "provide the basis for a vibrant and flexible system of 
employee relations in which the voices of organized workers... provide a healthy dose of countervailing economic and power." ${ }^{\prime 7}$ In 2001, the Canadian Supreme Court ruled that the Canadian Charter of Rights and Freedoms protects a worker's right to a representative body in the workplace, which seemed to underline the promise of this strategic option for Canadian workers. In Canada, labour scholar Roy Adams is the leading voice arguing for a change in the orientation of labour organization from what he calls a "Wagner Act model," based on the Rand formula and certified exclusive bargaining representation, to "I-Mode": a model of organizing workers based on human rights and Canada's international treaty commitments ro increasing worker representation. ${ }^{74}$

Claiming that "survey evidence indicates that many employees prefer informal non-statutory collective representation over certified exclusive agency," 75 Adams argues that unions must abandon their insistence on the traditional mechanisms of organizing and negotiation, and become willing to embrace works councils, employee representatives, and other non-exclusive forms of representation. How promising an option is this for fast food workers? Adams repeatedly cites his McMaster University faculty association as an effective employee organization. Of course, tenured faculty members have a level of power and security in the work force several orders above what a fast food worker does, making his association an extremely poor example for the utility of this model in the wider workforce. Adams recognizes this point, but does not consider that, irrespective of the successes of McMaster's tenured faculty, academic labour in Canada is now more insecure, precarious, and casualized than ever before. $^{76}$ As to works councils, we have already observed their ineffectiveness as a vehicle for the aspirations of fast food workers in Europe.

Indeed, serious doubts have been raised about the entire intellectual project of basing trade unionism in liberal concepts of rights through court rulings and legislation, rather than working-class power at the point of production. Dunmore v. Ontario, the ruling heralded by Adams as clearing the way for worker representation in agriculture, was dismissed as weak gruel by Butovsky and Smith, who point out that neither collective bargaining or the strike weapon were protected by the court's decision. They call the Agricultural Employees Protection Act, the Conservative government's response to the court ruling, a "supremely cynical piece of legislation permitting farm workers to form toothless "associations," without requiring employers to recognize them. The upshot was that agribusiness remained entirely free from any legal obligation to bargain collectively with its employees."77 A 2011 decision by the Supreme Court of upheld the ALEA as constitutional, and seems to affirm that collective bargaining and the right to strike are not protected. ${ }^{78}$ It is not certain, then, that the protections offered by the courts, which are based on perceived worker vulnera- 
bility, not working class strength, are useful in stimulating real organizing in sectors like agriculture or fast food. Eric Tucker argues, for example, that legal rights based on vulnerability are intrinsically unstable, for the courts will reverse them as soon as these workers gain strength. ${ }^{79}$

Adams's concepts of non-traditional organizing have also been criticized as a dangerous reorientation of workers' energy away from struggle and the development of working-class power towards a passive reformism dependent on sympathetic governments or favourable court rulings. Larry Savage asserts that rights-based organizing "downplay[s] or altogether ignore[s] the material dimension of collective worker action and the central role of economic conflict in the employment relationship" 80 that may garner some "symbolic victories" but "has done very little to change the balance of class forces in Canada." 81 While Savage raises many important reservations, I would again submit that the fatal flaw in Adams' formulation of right-based organizing is its unfeasibility. He offers no realistic scenario for how the major shifts in the orientations of the forces of capital, labour, and the state necessary for its realization would take place.

For instance, Adams advocates that the three form a tripartite council in order to plan how Canada would meet its international labour obligations, when, as Savage observes, there is no evidence of any desire to do so on the part of any of the parties. Nor is there any suggestion from Adams as to how this desire would be stimulated. In response to Savage's criticisms, Adams argues that the victories of the new social movements offer a template for workers to follow in pursuing rights-based labour relations. The labour movement and its allies should press home a moral campaign: "The notion of the union-free workplace is as morally reprehensible as "separate but equal" and "a woman's place is in the home." Drawing on international human rights standards, the civil rights movement and the women's rights movements were able to mount vigorous campaigns against those discredited notions." 82 Yet again, no suggestions are given about how this campaign would emerge or be waged, giving the impression he has reached for a convenient comparison rather than deeply considering the real and complex political and historical moments that those movements responded to and whether they hold relevance for this situation. Furthermore, there is no consideration of how labour and workers' experiences are profoundly gendered and racialized.

Still, Adams is to be commended for trying to find new solutions to an impasse that continually frustrates precarious workers, like those in Squamish, from organizing to improve their working lives. While Savage rightfully places class conflict and power at the centre of the organization question, his own proposed solutions: "Organizing precarious part-time workers in the service sector 
is not impossible, but does require a long-term strategic vision and plan involving multiple unions. Extending collective bargaining rights to workers through any number of non-statutory schemes is no replacement for organizing workers into real unions" lack concrete suggestions for future practice. ${ }^{83}$ Currently, several new models of worker organization are emerging. In the remainder of this paper we will consider some of them and evaluate whether they might offer solutions for organizing precariously employed workers.

The United Food and Commercial Workers (UFCW) is one traditional union that is heavily involved in new ways of engaging workers in the low-wage economy. It has experimented with members-only unionism by backing WalMart Workers for Change, an organization that is open to all Wal-Mart workers past and present. By gathering workers into representative organizations, it hopes to build a critical mass and then organize these workers into more traditional union structures. The UFCW is also responding to a developing phenomenon in Canada's low-wage economy: the increased reliance by major corporations on migrant contract labour, and the violation of those contracts. It has been active in working with migrant farmworkers in BC, along with grassroots groups like Justicia for Migrant Workers. ${ }^{84}$

The UFCW has also expanded its support of migrant workers into the restaurant sector. The union is currently backing a $\$ 10$ million dollar class-action lawsuit against Denny's Canada by a group of Filipino migrant workers who claim their contracts were violated by Denny's. As the use of migrant workers in the fast-food and restaurant sector becomes more and more common in Canada, alliances between migrant worker groups and the labour movement are one way that legal and political pressure can be used to increase representation of these workers. Unions need to engage these workers, and organize across lines of citizenship. Butovsky and Smith suggest that labour should strongly demand full citizenship for all foreign workers, regardless of how they arrived here: "such a drive could unite Canadian and migrant workers in a common struggle against the split labour market and for significant improvements in wages and working conditions." 85

Such a sweeping demand is beyond what the UFCW is currently advocating. There are also very real questions about the UFCW's record representing service workers. In her book Cashing in on Pay Equity? Jan Kainer criticizes the union for negotiating concessionary contracts with little resistance, being undemocratic, and having little presence in the daily working lives of its members. ${ }^{86}$ Are the UFCW's efforts in this area a real mobilization of migrants and service workers, or are they a SEIU-style attempt to grow the membership and dues payments from the top down, with little concern for democracy or social change? 87 
Workers' centres are another growing method of organizing workers without requiring a workplace majority or tying workers to one specific workplace. While their structure and activities vary, centres generally offer referrals for workers, create a place for workers to share knowledge, and support workers seeking better treatment at their workplace. In Canada, the Toronto Workers Action Centre and the Windsor Workers' Action Centre are groups that combine education and support for workers with community organization and legislative pressure.

Often workers battle simply for employers to observe the minimum health, safety and wage standards, both through direct action and political and legal pressures. However, workers' centres are also winning legislative victories that expand workers' rights. In New York, the Make the Road centre successfully pushed for anti-wage theft ordinances. The Workers' Defense Project in Austin was able to convince the city to pass a law requiring employers to provide rest breaks to increase safety. In Florida, a workers' centre supported by the Interfaith Worker Justice (IWJ) was able to get legislation enacted in Miami-Dade County increasing the penalties for employers who steal their employees' wages. IWJ itself, which brings together people of different religious faiths to press for workers' rights, is another example of how unconventional organizing is creating new coalitions. While evangelical Christian politics and pro-business labor policies have marched in lockstep in the US over the past three decades, IWJ is trying to change that dynamic by uniting spiritual people of different faiths who believe in justice for working people. ${ }^{88}$

In the United States, the restaurant sector has its own workers' centre. Active in many cities across the United States, the Restaurant Opportunities Center (ROC) supports restaurant workers in conflicts with employers, provides training, and pushes for legislation that would benefit restaurant workers. An example of a recent success was Philadelphia City Council's enactment of an ROC-backed bill that makes it illegal for credit card fees to be deducted from tips left by customers. One server estimated the legislation would save her $\$ 1,300$ per year. ${ }^{89}$

Labour scholar Janice Fine sees great value in workers' centres. She lauds them for training workers to assume leadership roles and raise their voice, and finds they are effective at enforcing existing labour laws and improving working conditions. Their bottom-up orientation ensures workers centres are, in Camfield's words "built on actually existing worker resistance" and "directly impacting workers' lives." Fine calls for the traditional labour movement to be more directly involved and supportive of worker centres. However, this is a relationship that must be carefully negotiated; more layers of bureaucracy may impair the responsiveness and militancy that make the centres effective. ${ }^{90}$ 
Strategies both old and new are at work in these emerging forms of worker organization. One of the best-known solidarity unions in the fast food sector is the Starbucks Workers Union (SWU), affiliated with the Industrial Workers of the World (IWW). Like the Wobblies of old, SWU workers do not have to organize their entire workplace to receive support from the union, and they carry their union card with them if they transfer to a different outlets. The SWU has won wage increases and more stable scheduling in Starbucks outlets in New York and Chicago, in addition to improving health and safety conditions, proving that a union doesn't necessarily need to be the certified bargaining agent in order to be a useful vehicle for workers. While traditional unionism at Starbucks in BC ended when the union was decertified in 2007, ${ }^{91}$ the SWU continues to press the company for better wages and conditions.

The IWW has also led a high-profile unionization campaign at the Minneapolis-St. Paul outlet of sandwich chain Jimmy John's. In this campaign, the IWW is attempting to become the certified bargaining agent in the workplace. This is an important step forward. As Julius Getman notes, US labour law may view minority union agreements that apply only to members as discriminatory, so it is important to engage the entire workforce whenever possible.

Getman also rightly cautions that minority unions that cannot claim to represent the entire workforce will be significantly handicapped by their minority status when negotiating with the employer. ${ }^{92}$ Minority unions may be a good starting point for organization, but they should not be considered an end in themselves.

Therefore, the IWW's attempt to build majority unions along democratic, worker-led principles is important and necessary. While the Jimmy John's Workers Union was unsuccessful in its first certification attempt, its activism continues. The National Labor Relations Board (NLRB) upheld an appeal of the campaign's narrow defeat, based on allegations of unfair practices by the employer. This grants the union another opportunity for a certification vote. Workers' innovative campaign to pressure the company into granting workers sick days has garnered international attention. The NLRB has filed a legal complaint against Jimmy John's for firing six workers who participated in the sick days campaign. ${ }^{93}$ Unlike workers centres, these examples of radical unionism are focused on building durable representation at specific workplaces. Also unlike workers centres, they are unlikely to receive funding or support from the mainstream labour movement (and it is unclear whether they would accept it). Their politics of radical direct action and hostility to business unionism ensure make alliances problematic. Solidarity unions also lack the durability and deeper pockets of more mainstream unions.

The IWW principles of solidarity unionism and direct action have combined with the ideas of community unionism and workers' centres to create 
some interesting workers' groups in the Pacific Northwest, where the Squamish campaign was defeated. In Oregon, the Portland Restaurant Workers Association (PRWA), a group open to all workers in this industry. The PWRA educates workers about their rights, and fights for members who have experienced "illegal or unethical" treatment. Like the ROCs, the PWRA also combines advocacy with professional development, training workers in skills like knife work and wine pairing in addition to its workplace action and outreach. It also connects workers rights with the public through its Diners Alliance. If a PWRA member is in conflict with their employer, an email alert is sent to Diner's Alliance members requesting they avoid patronizing that restaurant. This type of community action is reminiscent of the community unionism Dorothy Sue Cobble identifies as key to the success of mid-century waitress unions.

Another IWW-allied group that has won several victories for workers in the Northwest is the Seattle Solidarity Network (SeaSol). SeaSol is open to all workers and tenants and uses direct action to remedy grievances, which typically include wage theft, theft of security deposits, and refusals to make repairs or improve working conditions. After the group decides to tackle a particular issue, they give a demand for restitution to the employer or landlord; if the demands are not met they picket and leaflet at their place of business, home, or church. These tactics are similar to how the IWJ has found success by notifying the faith community of recalcitrant employers of their workers' grievances. SeaSol has won several cases in Seattle and inspired solidarity networks to form in Tacoma and Vancouver. One important difference between the solidarity network model and worker centres is that solidarity networks are conditional upon direct action by the affected workers. If SeaSol agrees to help a worker in an action, that worker is obligated to participate in the action and help others fight their grievances in the future. This emphasis on participatory action is intended to keep the organization from becoming a bureaucratic service organization, which is a danger for worker centres as they grow in size and complexity. ${ }^{94}$

While these new options for worker activism are growing, they are still in a fairly embryonic stage. As Fine cautions, their growth would create new challenges, and it remains to be seen whether these less formal, less funded forms of workplace action will have the durability and adaptability necessary to help win lasting gains for low-wage workers. SWU leader Daniel Gross points out other issues that apply to many of these groups: they lack a stable structure that might provide durability, and their dependence on continuous member mobilization, in one sense a strength, also raises fears of burnout. However, it is instructive and encouraging that many of these groups have found ways around the problems that stymied Wiebe and Lowinger, and so many other workers in the fast food industry. Their low overhead and grassroots nature make them responsive to the grievances of fast food workers. Low-wage service workers are 
the focus of their efforts, not a sideline for a manufacturing-focused union. The ability to take representation from job to job sidesteps some of the problems of turnover, and gives workers options no matter where they work.

Minority unionism also allows workers to begin working on their grievances almost immediately, without the need for a drawn-out certification process, or a campaign to win over the entire workplace that subjects workers to harassment and allows employers to pit workers against each other. The Canadian and American bargaining systems were designed for male manufacturing workers in vertically integrated industries" 95 and "not designed to protect vulnerable workers... in sectors like fast food." 96 Conversely, these new forms of organizing were created with the issues of low-wage workers in mind. As IWJ coordinator Dianne Enriquez says: "workers' centers are basically responding to the new economy we have,... It's a branch of the labor movement, but just a different model." 97

Despite these advantages, legitimate questions remain about the efficacy of these organizing models for fast food workers. If a Squamish workers or solidarity network had been available in 1998, it may well have helped Lowinger, Wiebe, and other workers confront Savage with their issues, and won some improvements on conditions, safety, and the sick leave policy. It might have even eliminated some of the harsh treatment they received from managers. However, Fine echoes Gross by pointing out that workers centers have small memberships and many lack a coherent strategy for growth. Their sustainability, especially financially, is uncertain. Furthermore, how would they have influenced the struggle in Squamish in the medium to long term? If Lowinger and Wiebe's complaints were met with a firing, something workers are legally protected from during a union drive, what would a workers' centre or solidarity network be able to do? Perhaps regain the job, but that fight could derail energy and resources from the original set of demands. In the long term, too, there are real questions as to whether a workers' centre could help create durable changes in a fast food workplace. Would a franchise owner temporarily acquiesce, then renege on whatever informal agreement he had reached? Without a contract, would workplace activism turn into the Sisyphean task of constantly refighting the same battles?

There is some promise in the leadership training and bottom-up militancy of workers' centres and solidarity networks, especially their facility for training leaders and providing experience in fighting and winning battles. Still, left unionists need to be involved in an ongoing project of creating durable, worker-led unions, as the IWW is attempting to do at Jimmy John's, Starbucks, and elsewhere, along radical lines of democracy, militancy, and direct action. The IWW unions combine a grounding of action in workers' leadership and daily experience with the intention of creating durable foundations for long-term radi- 
cal change on the job. Compared to unions like the CAW, they lack funds. However, this may not be as crucial a variable as it may first appear. No union has sufficient funds to match a McDonald's or Wal-Mart anyhow, and any campaign will depend on community support and membership mobilization and strength, two factors that do not depend on income. While the challenge is still daunting, a grassroots, sustained approach may yet bear fruit. The battles at Starbucks and Jimmy John's were not resounding victories for the IWW, but they definitely hold promise. ${ }^{98}$

Considering that more traditional mainstream unionism mainstream unionism has consistently failed to win contracts for these workers, the radical alternative is certainly worth a shot. In Vanessa Tait's study of poor workers' unions, she quotes Joann Wypijewski as saying that, "it took fifty years for workers to figure out industrial organizing. When it took off it was part of a mass movement." 99 Worker-led organizations, like workers' centres, the IWW, and solidarity networks offer the best hope building that movement, even if a breakthrough may yet take some time.

In concert with radical, direct-action unionism, it is my opinion that left unionists and labour scholars should continue to advocate for changes to labour law. There are several changes that could help these workers and workers in other industries. It would be foolish not to explore them, even if their enactment currently seems remote. I agree with Julius Getman that laws banning the replacement of striking workers would be a major refashioning of the terrain of class struggle, though that achievement seems almost inconceivable in this climate. I also agree with him that a law guaranteeing unions equal access to employees during campaigns could be of benefit, but, as Rosemary Warskett observes, it seems unlikely that this law could be effectively enforced. On the other hand, I disagree with his dismissal of card check laws as unimportant. The Squamish shows case that card check enables a quick response to workers' desires to unionize, and helps maintain momentum that would otherwise be lost under drawn-out certification elections readily subject to employer intimidation.

This is borne out by Kendra Coulter's study of retail organizing in the Toronto area in the early 1990s. One organizer concluded that, "the secret ballot vote in small workplaces is devastating. Women had a fear of the consequences, they generally believed that [the corporate representatives] knew which side of the line they were on and if the union didn't go through, they would be fired.... We had enough cards signed. We had convinced the women, they understood; their husbands had agreed. Everything was good but when it came out and it was time for the vote, people said 'oh my god, there are only fourteen of us.' They were scared that they were going to be picked out, because managers had talked to them for hours. It was the secret ballot vote that killed us."100 Finally, 
the single most effective legal change that would have benefitted the workers at Squamish would be a requirement that one union contract is negotiated before a union can be decertified. This would give the union a fair chance to show workers what it can do, and would prohibit corporations from using their superior resources to run out the clock during disputes with workers. However, enacting new labour laws should be a secondary goal. The primary agenda for left unionists should be building democratic, radical unions that can win agreements in this sector, no matter the legal climate.

In the 1970s, the high turnover, low wages, employer surveillance, and intimidation experienced by fast food workers was, if not anomalous, then at least outside the ideological mainstream of Fordist capital-labour relations in North America. In 2011, the insecure, precarious work of the fast food sector is much more representative of North American work as a whole. While Ritzer's theory of McDonaldization is underhistoricized in ignoring how casualized, lowwage labour has long been central to the restaurant economic model, he is correct to point out that growth of employment in the fast food sector is an important and influential development in work under capitalism. As Royle notes, the struggle over labour relations in fast food is no less than a contestation of "the orthodoxy of economic liberalism... in which multinationals roam the globe in search of bigger profits, inadequately fettered by existing regulation."101 The experiences of these workers, especially their increased contingency, location in the growing food and retail sector, and deskilled labour has set a pattern. They are cornerstones of what has happened to work in the West over the past fifty years. In particular, they are where we need to look to understand the unceasing assaults on unions, rising inequality, diminished upward mobility, and corporate structures built on surveillance, control and fear. Fortunately, these fast food jobs may also be a laboratory for new forms of worker organization that win real gains for working people. The Squamish campaign may have ended in defeat, but it will have not have been in vain if its lessons are heeded by scholars and activists alike.

\section{NOTES}

${ }^{1}$ Befitting an industry that has had such an enormous global impact, there has been some excellent work done on fast food by scholars in both Canada and abroad. In Canada, see Ester Reiter, Making Fast Food: Out of the Frying Pan and into the Fryer (Montréal: McGill-Queen's University Press, 1993); Reiter, "Life In A Fast Food Factory" in On the Job: Confronting the Labour Process in Canada, ed. Craig Heron (Montreal: McGill-Queen's University Press, 1986), 309-26; and Ester Reiter "Fast-food in Canada" in Labour Relations in the Global Fast Food Industry, ed. Royle and Towers, (London: Routledge, 2002), 26. Royle and Towers' collection is the best current work on fast food labour internationally. Other 
important international scholarship on working McDonald's includes Tony Royle, Working for McDonald's in Europe: an Unequal Struggle, (London: Routledge, 2002); Robin Leidner, Fast Food, Fast Talk: Service Work and the Routinization of Everyday Life, (Berkeley: University of California Press, 1993); Jennifer Parker Talwar, Fast Food, Fast Track: Immigrants, Big Business, and the American Dream, (Cambridge: Westview Press, 2002). In addition to this fast-food specific literature, several notable studies have analyzed restaurant unionization. See Howard Kimeldorf, Battling For American Labor: Wobblies, Craft Workers, and the Making of the Union Movement, (Berkeley: University of California Press, 1999); in Canada, see Janet Nicol, “Unions Aren't Native: The Muckamuck Restaurant Labour Dispute, Vancouver, BC (1978-1983)," Labour/Le Travail 40 (Fall 1997), 235-51 and Julia Smith, "Organizing the Unorganized: The Service, Office, and Retail Workers Union of Canada (SORWUC), 1972-86 (MA Thesis, 2009), available at http://summit.sfu.ca/item/9826. An interesting history of the main union in the sector, the Hotel and Restaurant Employees (HERE) that also evaluates HERE's contemporary use of comprehensive organizing campaigns, is Julius Getman, Restoring the Power of Unions: It Takes A Movement, (New Haven: Yale University Press, 2010). Unfortunately, Getman's book has very little to say about the fast food workplace or HERE's indifference to organizing it. An account of an early US fast food unionizing campaign appears in Vanessa Tait, Poor Workers Unions: Rebuilding Labour From Below, (Cambridge: South End Press, 2005), 107-09.

2 On the postwar settlement, see Bryan Palmer, Working Class Experience: The Rise and Reconstitution of Canadian Labour, 1800-1980. (Toronto: Butterworth, 1983), 245-55; Joan Sangster, Transforming Labour: Women and Work in Post-war Canada, (Toronto: University of Toronto Press, 2010), 3-5; Leah Vosko, Precarious Employment: Understanding Labour Market Insecurity in Canada, (Montreal: McGillQueen's University Press), 6; A good recent summary of the rise of neoliberalism in Canada in the last four decades can be found in Thom Workman, If You're In My Way, I'm Walking: The Assault on Working People Since 1970, (Halifax:

Fernwood Publishing, 2009).

${ }^{3}$ Ben Isitt, Militant Minority: British Columbia Workers and the Rise of a New Left, 1948-72, (Toronto: University of Toronto Press, 2010), 292.

4 Ernest B. Akeyampong, "Unionization, an Update," Perspectives on Labour and Income (August 1999), 48, accessed online 7 December 2011, http://www.statcan.gc.ca/studies-etudes/75-001/archive/e-pdf/4686-eng.pdf.

5 John Schreiner, "McDonald's is a Trophy for the Canadian Auto Workers: Newly Unionized Burger Outlet in Squamish is a Symbol of a Changing Workforce," Financial Post, 28 August 1998; Jennifer Prittie and Donna LaFramboise, "Union Finds McDonald's Pitch No Small Potatoes," Windsor Star, 15 August 1998.

${ }^{6}$ Stuart Tannock, Youth at Work: The Unionized Fast-food and Grocery Workplace, 
(Philadelphia: Temple University Press, 2001). Also on CAW 3000, see Jeremy Milloy, "Fast Food Alienation: Service Work and Unionization in British Columbia, 1968-1998" (MA Thesis, 2007), available at http://ir.lib.sfu.ca/handle/1892/11042

7 Workplace activism by customers, many of whom were union workers themselves, was often a crucial intervention in restaurant unionization campaigns in the 1930s. See Dorothy Sue Cobble, Dishing it Out: Waitresses and Their Unions in the Twentieth Century, (Chicago: University of Illinois Press, 1991), 98-99. Cobble discusses community actions like the "sip in," in which pro-union patrons would occupy the restaurant, ordering just coffee for hours at a time, to apply economic pressure to an anti-union employer. Cobble identifies wider union membership as a key dynamic in helping restaurant unions become established in many communities.

8 James Risdon, "Does He Deserve a Break Today? A Squamish McDonald's Franchisee Takes on The Canadian Auto Workers," BC Report. 19, April 1999, Vol.10,.12, 34 .

9 Dene Moore, “Teens Take On Fast Food Giant." Canadian Press, 23 August 1998.

10 John Gray, "Is Labour's Mac Attack A Losing Battle?" The Globe and Mail, 9 September 1998.

11 Schlosser, 88; Leidner, 81-82.

12 Reiter, Making Fast Food, 135. More recently, Eric Schlosser discusses the McDonald's strategy of "transactional analysis" or "stroking” young workers: giving them positive feedback and instilling a team or family dynamic in place of wage raises or benefits; 74 .

13 Reiter, Making Fast Food, 36.

14 Details on working while sick from Moore; Lowinger's quote from Liza Featherstone, “The Burger International,” Labour/Le Travail 43, Spring 1999, 301-306.

15 Schlosser, 82.

16 Reiter "Fast-food in Canada," 42.

17 Jacquie Charlton, "Refusing to Swallow the Burger," Montreal Mirror, 22 June 1998, http://www.montrealmirror.com/ARCHIVES/1998/022698/news5.html, accessed 28 June 2011.

18 Talwar, 189.

19 “McDonald's Employees Vote to Certify Union," Canadian Press, 19 August 1998.

20 Dan Zuberi, Differences That Matter: Social Policy and The Working Poor in The United States and Canada, (Ithaca: Cornell University Press, 2006), 53-54.

21 Petti Fong, "McDonald's Workers Split On Union," Vancouver Sun, 18 August, 
1998.

22 Moore; Canadian Press.

23 Royle and Towers, "Summary and Conclusions: MNCs, Regulatory Systems, and Workers' Rights," in Labour Relations in the Global Fast Food Industry, 192-203.

24 Reiter, "Fast-food in Canada," 42-43.

25 Milloy, "Fast Food Alienation: Service Work and Unionism in British

Columbia, 1968-1998” (MA Thesis, 2007), 20-21; available online at

http://ir.lib.sfu.ca/handle/1892/11042

26 CP, "McDonald's Workers Certify Union."

27 Editorial, "The Golden Thud". Vancouver Province. 23 August 1998.

28 Kelly Sinoski, "Squamish McDonald's Staff Taste-Test a Contract," Vancouver Sun, 5 March 1999.

${ }^{29}$ George Ritzer is perhaps the most influential and controversial thinker about the influence of McDonald's. See George Ritzer, The McDonaldization of

Society, (Thousand Oaks, California: Pine Forge Press, 2004). For critics of the McDonaldization theory, see especially Barry Smart, ed., Resisting

McDonaldization (Thousand Oaks, California: Sage, 1999).

30 Julia Woodhall and Alicia Muszynski, "Fordism at Work in Canadian Coffee Shops," Just Labour 17 \& 18 (2011), 67, accessed 7 December 2011, http://www.justlabour.yorku.ca/volume17/pdfs/05_woodhall_muszynski_press. pdf.

31 Talwar, 189-90; Royle describes McDonald's work process as Taylorist and Fordist in "Summary and Conclusions," Working for McDonald's in Europe, 21; on McDonald's stymieing works councils see Royle, Labour Relations in the Global Fast Food Industry, 203-04; and also the other contributors to that volume.

32 Sinoski, "Squamish McDonald's Staff."

33 The BC KFCs represented by Local 3000 are a unique case. Unlike Savage's McDonald's, the KFCs were originally owned by White Spot, whose owner Nat Bailey purchased the KFC recipe and rights for the territory of British Columbia. Fearing an organizing drive by the Hotel and Restaurant Employees Union, Bailey organized White Spot and KFC workers into a company union. After Bailey sold the restaurants to General Foods in 1968, workers at the restaurants gradually organized the company union into an actual trade union.

Crowther should thus have been aware that the situation in Squamish differed in many important respects. For more on the KFC certification, see Milloy, "Fast Food Alientation: Service Work and Unionism in British Columbia, 1968-1998", MA Thesis, 2007, available at http://ir.lib.sfu.ca/handle/1892/11042

34 Chad Skelton, “McDonald's Union Faces Vote," Vancouver Sun, 29 June 1999. 35 [1999] B.C.L.R.B.D. No. 445, paragraph 17.

36 CAW 3000, "Notice Of Strike Vote," 4 December 1998. 
86 Milloy

37 [1999] B.C.L.R.B.D. No. 445, paragraph 23.

38 [1999] B.C.L.R.B.D. No. 445, paragraph 22.

39 Letter from Crowther and Kellahan to CAW 3000 members, 3 June 1999.

40 Letter from Savage to all employees, 11 December 1998.

41 Letter from Savage to all employees, 30 December 1998; Paul Savage, "Negotiaions Update," 15 November 1998.

42 John Gray, "Is Labour's Mac Attack."

43 Interview with Denise Kellahan, 21 February 2007.

44 John Gray, "Is Labour's Mac Attack."

45 Letter from Savage to all employees, 10 June 1999.

46 Letter from Savage to all employees, 11 December 1998.

47 Reiter "Fast-food in Canada," 44.

48 "Squamish McDonald's Workers Near Landmark Agreement," Vancouver Sun, 8 March 1999.

49 Chad Skelton, "Squamish McDonald's Workers to Vote on Decertifying Union," Vancouver Sun, 29 June 1999.

50 All quotes in this section from David Hogben, "Squamish McDonald's Employees Vote to Decertify," Vancouver Sun, 3 July, 1999.

51 Christina Montgomery, "A Big Mac -- And Hold the Unions," Vancouver Province, 4 July 1999.

52 Montgomery, "A Big Mac."

53 Gavin McGarringle, "Hope in Hospitality: Winning a First Contract at the Cheesecake Café," Our Times 18, Jul-Sep 1999, 31.

${ }^{54}$ For an excellent overview of the history and mechanics of comprehensive campaigns, coupled with a judicious evaluation of their strengths and weaknesses, see Julius Getman, Restoring the Power of Unions: It Takes A Movement, (New Haven: Yale University Press, 2010).

55 On this topic, see Naomi Klein, No Logo: Taking Aim at the Brand Bullies, (Toronto: Vintage Canada, 2000), 347-50.

56 Royle, Working for McDonald's in Europe, 39-57.

57 Dave Cunningham, "Brother Ronald McDonald: A Shift to the Service Sector Helps Unions Maintain Their Power in the Province," BC Report 48, 7 September 1998, 32.

58 Royle and Towers, "MNCs, Regulatory Systems, and Employment Rights", 195.

59 An older, but still highly relevant study of why Canadian labour law works against service workers can be found in Rosemary Warskett, "Bank Worker Unionization and the Law," Studies in Political Economy 25 (1988), 41-73. 
60 Interview with Laurie Banong, "Baristas Of The World Unite! (First Anniversary Of The Union Drive)," Labour/Le Travail 42, Fall 1998, 335-343.

61 "Interview with Bonang."

62 Anthony Bianco, "No Union Please, We're Wal-Mart," Business Week, 13

February 2006.

63 Vosko, 3.

${ }^{64}$ Kate Bronfenbrenner and Tom Juravich, "It Takes More Than House Calls:

Organizing to Win with a Comprehensive Union-Building Strategy," in Organizing to Win: New Research on Union Strategies, (Ithaca: Cornell University Press, 1998), 19-36.

65 Getman, 309.

66 Steve Early, Embedded With Organized Labour: Journalistic Reflections on the Class War at Home, (New York: Monthly Review Press, 2009); Getman, 160-175.

67 Butovsky and Smith, 71.

68 David Camfield, Canadian Labour in Crisis: Reinventing the Workers' Movement, (Halifax: Fernwood Publishing, 2011), 120-21.

69 LaFramboise and Prittie, "McDonald's a Test Case For Unions," Vancouver Sun, 15 August 1998.

70 Tait, 107-09.

71 Getman, 307.

72 Wade Rathke, “A Wal-Mart Workers Association? An Organizing Plan,” in Wal-Mart: The Face of Twenty-First Century Capitalism, ed. Nelson Lichtenstein (New York: The New Press, 2006), 261-284; 275. Non-traditional organizing is a much-discussed subject among labour; see also Janice Fine, "Why Labor Needs A Plan B: Alternatives to Conventional Trade Unionism," New Labor Forum 16, Spring 2007, 35-47.

73 Charles Morris, The Blue Eagle at Work: Reclaiming Democracy in the American Workplace, (Ithaca: Cornell University Press, 2005), 13.

74 Roy Adams, "From Statutory Right to Human Rights: The Evolution and Current Status of Collective Bargaining" and "I-Mode, The New Language of Workers' Rights: A Response to Larry Savage”, Just Labour 12, (2008) 48-66 and 76-85.

75 Adams, "From Statutory Right," 60.

76 Adams, "I-Mode," 80.

77 Butovsky and Smith, 81.

78 Julius Melnitzer, "Fraser Decision Reveals Judicial Debate Over Bargaining Rights," National Post, 3 May 2011, accessed 7 December 2011, http://business.financialpost.com/2011/05/03/fraser-decision-reveals-judicialdebate-over-bargaining-rights/\#more-49713 
79 Tucker is quoted in Larry Savage, "From Labour Rights to Human Rights? A Response to Roy Adams," Just Labour 12, (2008), 68-75.

80 Savage, 68.

81 Savage, 75.

82 Adams, "I-Mode," 85.

83 Savage, 74.

84 Suzanne Fournier, "Migrants Slam 'Union Blacklists'," Vancouver Province, 15 November 2011.

85 Butovsky and Smith, 88.

86 Jan Kainer, Cashing in on Pay Equity? Supermarket Restructuring and Gender Equality, (Toronto: Sumach Press, 2002).

87 On the activism and lawsuite at Denny's Canada, see "UFCW Supports OFW's \$10M Class Action Suit vs Denny's", Phillipine Reporter, 28 January 2011. Accessed 26 November, 2011.

http://www.philippinereporter.com/2011/01/28/ufcw-supportsofws $\%$ E2 $\% 80 \% 99-10$ m-class-action-suit-vs-denny $\% \mathrm{E} 2 \% 80 \% 99 \mathrm{~s} /$, ${ }^{88}$ For an excellent analysis of the integral connections between precarious labour and evangelical Christianity in postwar US history, see Bethany Moreton, To Serve God and Wal-Mart: The Making of Christian Free Enterprise, (Cambridge: Harvard University Press, 2010).

89 See "ROC Philadelphia Wins Legislative Victory- Protects 26,000 Workers From Wage Theft!" accessed 1 December 2011, http://rocunited.org/uncategorized/roc-philadelphia-wins-legislative-victory-protects-26000-workers-fromwage-theft/

90 Karen Loew, "Worker Centers: A Clubhouse for Struggle, Support," Jewish Daily Forward.com, 23 March 2011 (Appeared in print 1 April 2011), accessed 6 December 2011, http://www.forward.com/articles/136435/; Janice Fine, "Worker Centers and Immigrant Women," in The Sex of Class: Women Transforming American Labor, ed. Dorothy Sue Cobble (Ithaca: Cornell University Press, 2007). 91 "Last BC Starbucks Outlets Cut Ties to Union", Vancouver Sun, 28 April 2007, accessed 6 December 2011, http:/ /www.canada.com/vancouversun/news/business $/$ story.html?id $=03907014-\mathrm{f} 696-47 \mathrm{~d} 3-\mathrm{a} 3 \mathrm{e} 1-\mathrm{cf} 29 \mathrm{e} 49 \mathrm{f} 0359 \mathrm{k}=35134$. While the union negotiated three contracts with Starbucks and had some impact on shift scheduling and job language, they never made significant progress on wages and benefits. CAW organizer John Bowman also cited high turnover as a significant factor dampening union solidarity and durability.

92 Getman, 300-01.

${ }^{93}$ Daniel Gross and Staughton Lynd, "Solidarity Unionism at Starbucks," PM Press Blogs, http://www.pmpress.org/content/article.php/20080722202202555, accessed 6 December 2011; “Jimmy Johns Fires Workers after Sick Day 
Campaign", Reuters, 30 March 2011, http://blogs.reuters.com/shoptalk/2011/03/30/jimmy-johns-franchise-fires-union-workers-after-sick-day-campaign/, accessed 31 March 2011; Mike Hughlett, "NLRB Says Jimmy John’s Didn’t Play Fair,” Minneapolis Star-Tribune, 9 November 2011.

94 On the PWRA, I have drawn on my conversation with a PWRA organizer, and their website, online at http://pdxrwa.org/. On SeaSol, see "SeaSol, Why You Should Start a Solidarity Network, "http://thetbf.wordpress.com/2011/02/02/why-you-should-start-a-solidaritynetwork/, accessed 27 April 2011.

95 See Peter McInnis, “Teamwork for Harmony: Labour-Management Production Committees and the Postwar Settlement in Canada", Canadian Historical Review Vol. 77 No. 3, 1996, 317-52; Ann Porter, Gendered States: Women, Unemployment Insurance, and the Political Economy of the Welfare State in Canada, 1945 97, (Toronto: University of Toronto Press, 2003;) Pamela Sugiman, Labour's Dilemma: The Gender Politics of Auto Workers in Canada, 1937-1979 (Toronto: University of Toronto Press, 1994), Leah Vosko, Precarious Employment: Understanding Labour Market Insecurity in Canada, (Montreal: McGill-Queen's University Press); on the US, see Moreton, To Serve God and Wal-Mart, 60-61. 96 Reiter in Labour Relations in the Global Fast-Food Industry, 38.

97 Karen Loew, "Worker Centers: A Clubhouse for Struggle, Support."

98 To read more about direct or solidarity unionism, see Anonymous, "Direct Unionism: A Discussion Paper," accessed 7 December 2011, http://libcom.org/library/direct-unionism-discussion-paper-09052011; Black Orchid Collective, "Response to 'Direct Unionism: A Discussion Paper'," Black Orchid Collective, accessed 7 December 2011, < http://blackorchidcollective.wordpress.com/2011/08/11/response-to-direct-unionism-a-discussion-paper/>; Juan Conatz, "A Response to 'Direct Unionism: A Discussion Paper," accessed 7 December 2011, http:/ /libcom.org/blog/response-direct-unionism-discussionpaper-part-1-2-15052011; Part Two, http://libcom.org/blog/response-directunionism-discussion-paper-part-2-2-20052011; and finally Juan Contraz, "Another Response to Direct Unionism,"; Sean G. "Counterpoint," accessed 7 December 2011, Recomposition Blog, <http://recompositionblog.wordpress.com/2011/11/20/another-response-todirect-unionism-and-a-counterpoint/ $>$.

99 Tait, 209.

100 Kendra Coulter, “Unionizing Retail: Lessons From Young Women’s Grassroots Organizing in the Greater Toronto Area in the 1990s," Labour/Le Travail 67 (Spring 2011), 86.

101 Royle, Working for McDonald's in Europe, 211. 